\title{
Private Property in Communist Czechoslovakia
}

\section{Jan Demela, Štěpán Mikula ${ }^{1}$}

\begin{abstract}
This article analyses the development of legislation regarding private property in Czechoslovakia between 1948 and 1989 and summarizes available empirical data relating to property rights protection in the given period. Although the legislation took gradual steps towards diminishing the status of private property, no laws were passed that officially or entirely terminated its existence. The legislation of the 1960 s set a status quo which codified property rights until the fall of the Communist regime in 1989. Most of the empirical data, which are available only for the 1980s, do not show any significant trend, corresponding with the unaltered situation in the legislation of that decade.
\end{abstract}

Key words: private property, property rights, legislation, empirical data, communism, Czechoslovakia

JEL Classification: P26, N44, K11

Received: 6 February 2015 / Accepted: 3 September 2015 / Published: 30 September 2015

\section{Introduction}

Economic literature pays close attention to the issue of property rights. It defines a number of different concepts of property rights and their impact on the functioning of real economy documented both at macro and micro levels. However, our knowledge of private property and its protection in Communist Czechoslovakia and other countries of the Eastern Bloc is insufficient. This information deficiency seriously limits research possibilities in political and institutional economics, such as research into property rights in autocratic regimes or the influence of initial conditions on the transformation of centrally planned economies.

This paper analyses the development of property rights protection in Communist Czechoslovakia using two complementary approaches. Firstly it summarizes the development of legislation regarding private property in Communist Czechoslovakia between 1948 and 1989. Secondly the empirical data, which are available only for 1980s, and their development are investigated in the context of Eastern Bloc using descriptive statistics. The outcomes of both approaches are compared. Therefore the paper provides a

\footnotetext{
${ }^{1}$ Masaryk University, Faculty of Economics and Administration, Department of Economics, Lipová 41a, Brno 602 00, mikula@econ.muni.cz, 348573@ @ail.muni.cz
}

(C) 2015 by the authors; licensee Review of Economic Perspectives / Národohospodářský obzor, Masaryk University, Faculty of Economics and Administration, Brno, Czech Republic. This article is an open access article distributed under the terms and conditions of the Creative Commons Attribution 3.0 license, Attribution - Non Commercial - No Derivatives. 
comprehensive overview of information available on property rights protection in communist Czechoslovakia.

The Communist ideology rejects private property as a cornerstone of capitalist exploitation. Yet, terminating private property paralyses basic functions of the market system, which must then be replaced, at least at a theoretical level, with a system of central planning. In Communist Czechoslovakia such a central plan was meant to de facto secure balance in the economy.

The principles of central planning demand that all the agents of the respective economy adhere to a plan set by the state or another, higher, authority capable of enforcing its will over the will, needs, and desires of the subordinate agents. Therefore, the centrally planned system is conditional upon the termination or at least radical restriction of property rights. Property rights must be surrendered to the plan-setting authority which actually disposes of the resources. With this in view, we can say that central planning is in opposition to independently performed property rights.

In terms of actual governance, a different perspective can be applied to property rights in the Communist economies. All of these economies functioned as autocracies led by a limited interest group - the Communist Party as the "leading power in the society and state" (Act No. 100/1960 Coll). The establishment of such limited Communist Party governance can be interpreted as a large-scale expropriation, where the new owner of the expropriated property is the Communist Party itself. The actual proprietors of the property are those who are in real possession of the expropriated property, use it and benefit from it, i.e. the Communist Party leaders, or those in authority who exercise direct influence on the decision making process (see, for example Mlčoch, 1990, 2000). This definition in fact makes no difference between the ideology-driven Communist autocracy and any other form of autocracy which violates the property rights of the previous, legitimate, owners.

Despite their ideology, Communist autocracies did tend to exercise a certain degree of protection of property rights, in particular the property rights of the leading elite (hence the law persecuting misappropriation of socialist property and sponging), but also, paradoxically, property rights for ordinary citizens. The reason for this latter was the potential threat of disorder and expressions of disobedience which might be triggered by an extremely restrictive policy, which might eventually jeopardize the Communist Party's authority in the society and the economy and thus could result in the loss of the property rights (and their benefits) by the governing elite. The relevance of this hypothesis is well demonstrated by the economic policies observed in most of Communist autocracies still in existence today and in the empirical results presented by Mikula (2012), who does not find any significant difference in the level of protection of property rights between communist and non-communist autocracies.

Another factor contributing to at least a partial adherence to property rights on the part of Communist regimes is the (supposed) dysfunctionality of central planning. Should the central plan not be able to completely allocate all resources, this would allow for personal initiative, which, however, is conditioned by at the very minimum the existence (and protection) of elementary property rights. 
The development of the property rights standards in Czechoslovakia is described in Chapter 2 - in which available sources are used to analyze formal legislation relating to property rights in the given historical period - and in Chapter 3, which presents an analysis of empirical data. Chapter 1 offers a complex view of the definition of property rights.

\section{Definitions of property rights}

This chapter presents an overview of various definitions of property rights based on Roman Law and a representative sample of economic literature. The definition of property rights forms the basis of further discussion concerning their protection and interpretation.

Modern legal systems are based on Roman Law and its definition of property and ownership logically reflects on respective codifications and definitions offered by individual authors. Under Roman law property rights are defined in terms of dominion over res direct possession of and the exclusive right to a tangible res. The owner is free to dispose with his property as he feels fit, that is, in a plenary manner, and hence the right is deemed to be universal. Nonetheless, possessory rights can be delineated. Moreover, the owner has dominion and control over his res (ius possidendi), full use of the res (ius utendi), the right to enjoy the res (ius fruendi) and the right to destroy the res at will (ius abutendi). The owner has the right to dispose of his res, that is, to appropriate it or transfer his possessory rights to the res to others (ius disponendi) (see Kincl, Urfus, \& Skřejpek, 1995).

The influence of this Roman Law definition of property rights is evident even in modern economic literature. According to Demsetz (1996), property rights (or private property) represent an individual's control over all possible effects resulting from the possession of scarce resources (including intellectual property). These rights can be transferred to other individuals. In another work, Demsetz and Alchian (1973) define property rights as rights to use scarce resources according to the free will of the proprietor. However, these rights are circumscribed by rules and prohibitions. Similarly, De Alessi (1983) describes private property rights as an individual's exclusive and transferable rights to use such resources. Leblang (1996) offers a similar definition: an individual has the rights of possession of property that he or she owns, and these rights are respected by others. Such an individual's property rights are conditioned by his or her ability to dispose of the property and alienate it. North (1990) likewise defines property rights as rights to use and enjoy scarce resources as well as rights to appropriate such resources.

Barzel (1997) further divides property rights into "economic property rights" (EPR) and "legal property rights" (LPR). LPR are defined by legal regulations and enforced by means of state authority. EPR reflect an actual situation and refer to those who in fact perform and enjoy property rights. Therefore, subjects of EPR are not necessarily identical with subjects of LPR. Barzel claims that Alchian's definition of property rights applies to EPR, but not LPR. Barzel defines property rights as an individual's rights to consume a property or service, either directly or indirectly by means of exchange. Even though Barzel's definition of EPR may seem identical to the Roman Law definition, these two concepts are not in fact the same. Both concepts similarly define the owner's 
partial rights. However, in Roman Law, property rights are guaranteed by the state and enforceable by legal proceedings, while EPR are not necessarily subject to state protection and may be enforceable by other means than legal proceedings.

Williamson (1996) applies a similar approach to Barzel's, stressing the difference between property rights de facto and de iure.

In Czech economic literature, analysis of property rights in the specific conditions of the Communist planned economy in Czechoslovakia can be found in Mlčoch (see Mlčoch, 2000). With reference to actual business operations of enterprises he describes quasiproperty rights, where the actual execution of property rights is detached from formal, legal institutions. Mlčoch thus joins mainstream economic theory, which differentiates between formal declarations and the real situation in the property rights environment.

Economic literature dealing with property rights puts more emphasis on the real functioning of these institutions, while jurisprudence naturally concentrates more on their formal and legal definitions.

Various degrees of difference between the legal definitions of property rights and their real implementation and functioning can be found, in virtually all economies. For this reason, the economic approach seems to be more convenient as it takes into account the real conditions encountered by economic subjects. This applies to economies where the formal and real institutions are in direct discord, as well as to economies where such discord may be expected. Centrally planned socialist economies are a telling example of such systems.

This study works with the definition of property rights as real execution of property rights by natural persons lacking any authoritative position in the system. The emphasis on the real functioning of property rights corresponds both to empirical indicators in the second part of the study and to economic theory.

\section{Formal codification of private property}

The Communist coup d'etat of February 1948 brought about a dramatic change in the conception of the state and the law in Czechoslovak society. The Communist Party policy of a centrally planned economy fundamentally altered the codification of property rights in the new legal system. The "Two-Year Plan for Law" of 1949-1950 restructured the existing legal system. A new Civil Code (codifying property rights, among other matters) came into force as late as January 1, 1951.

Regardless of the political putsch, the Parliament went on preparing a new Constitution which was passed on May 9, 1948. The new Constitution included provisions securing basic human rights and freedoms. Even though these respective sections of the Constitution were never formally amended in the following years, legislative, administrative, and political interventions and regulations turned them into empty, powerless declarations (see Jánošíková et al., 2010, pg. 152).

Article XII of the Constitution defined the Czechoslovak economic system as based on nationalization of natural resources, industry, finance and banking, and land ownership according to the proclamation "the land belongs to those who work on it". It also codi- 
fied the protection of private and medium-sized enterprises and the inviolability of personal property. The Constitution also guaranteed private agricultural land ownership up to 50 hectares.

The spring of 1948 saw the second phase of post-war nationalization, according to Act No. 114 and 115/1948 Coll. The range of industrial sectors in which all enterprises were subject to nationalization was significantly widened. In some sectors, expropriation criteria were based on the degree of technological equipment or the volume of yearly output (e.g. saw mills, brickworks, mills, etc.). In other industrial sectors, expropriation applied to enterprises with more than 50 employees. Among enterprises that were nationalized were wholesale companies, foreign trade companies, travel agencies, the printing industry, and health resorts. Although the law offered compensation for the expropriated property, owners were hampered in claiming this compensation by an overly complicated system, so that in reality there was no compensation granted at all (Průcha et al., 2009, pg. 199-200). It is not surprising that the promised implementation regulations on compensation allocations were never passed (Kuklík, 2010, pg. 313). Another wave of nationalization in December 1948 swallowed the rest of the privatelyowned railways, public road transportation, and air and water transportation.

\section{Codification of Property Rights in the Civil Code of 1950}

The new Civil Code of 1950 defined three basic forms of property: socialist property (either state-owned or cooperative-owned), personal property, and private property. National property was solely socialist property. Socialist property could be stolen or misappropriated only within the bounds of standard economic operations and management, and could not be transferred to private hands.

Personal property comprised mainly items for personal use, family houses and incomegenerated savings. Personal property was declared to be inviolable. The Civil Code further specified regulations defining private property as such that could not be considered either socialist or personal.

The differentiation between personal and private property must be regarded as an ideologically motivated measure. In fact, both of these legal forms of property concerned natural persons' property and therefore both personal and private property (as then specified by the law) may be generally considered to be private property.

It is important to mention that with the implementation of the new Civil Code Czechoslovak legislation abandoned the Roman legal principle "superficies solo cedit" (the surface yields to the ground). According to the new law, a building no longer belonged to the owner of the ground on which it stood. One of the reasons why this law came into force was the need to facilitate the growth of agricultural cooperatives (JZD). Although the cooperative was not in fact the owner of the cooperative-managed land (which belonged to the respective members of the cooperative), the law allowed the cooperative to use the land as a building site for cooperative activities.

Property rights were further restricted by a number of other, often purpose-made, legislative acts and administrative regulations. Examples of these are laws abused by the Communist Party with a view to enforcing cooperative membership and limiting private entrepreneurship. 


\section{The 1960 Constitution and Changes in the Civil Law}

In 1960, Czechoslovakia declared successful implementation of socialism and adopted a new Constitution (Constitutional Act No. 100/1960 Coll.). The new Constitution defined socialist property (state-owned, national property) and cooperative property as basic forms of property. The Constitution granted the rights to small-size entrepreneurship (mainly agricultural) based on the owner's personal labour, provided it was not based on the exploitation of other people's labour. Personal property rights (incomegenerated savings, consumer goods, items for personal and household use, and family houses) were declared to be inviolable. ${ }^{2}$ The Constitution made no amendments regarding private property.

The construction of a socialist society heading towards Communism demanded changes in the Civil Law. In 1964, a new Civil Code, Act No. 40/1964 Coll. came into force, which eliminated traditional Civil Law institutions, such as possession, positive prescription, easement, and lease. Some of these institutions were replaced by new concepts. For example, "service" became the dominant term in the obligation law, replacing contracts and agreements. Services regulated relationships between the citizens and socialist organizations (Bělovský, 2009, str. 437).

The new Civil Code dealt only with private property in part eight. The fact that this institution was included at the very end of the Civil Code indicates that the ideology of the regime considered it to be an inferior form of property, which corresponds to the fact that the 1960 Constitution made no amendments to private property legislation at all. However, the Civil Code did not take any steps towards terminating private property, which remained inheritable. Socialist property was further amended by Act No. 109/1964 Coll. Removing this form of property rights from the authority of the Civil Code resulted from efforts to bring control over state property management under the authority of the Economic Code (Bělovský, 2009, pg. 446). Socialist property was defined as state and cooperative property. Officially, the proprietors were all working citizens, whose duty was to protect their common property.

\section{Private Land Ownership}

The process of structural change in land ownership started with Act No. 46/1948 Coll. on land reform - which put one of the principles of the Communist agricultural program (referred to as Hradecký Program) into practice - and the Constitution claiming that "the land belongs to those who work on it". The law did not allow individual ownership of more than 50 hectares land. Even smaller acreage could be liable to nationalization if it was not consistently worked on or owned by a legal person.

The implementation of the land reform went hand in hand with what was termed "socialization of the village", which was characterized by collectivization in agriculture.

\footnotetext{
${ }^{2}$ Inviolability was solely restricted to personal property. The Civil Code (Act No. 40/1964 Coll.) $\S 130$ article. 2 stipulated: "Property accumulated contrary to the interests of the society and exceeding the personal needs of the owner, his or her family and household are not subject to personal property inviolability".
} 
Agricultural cooperatives were divided into four basic types, differing in their degree of collectivization. In its early stages collectivization was voluntary, but as of 1950 agricultural labourers were forced to join the cooperatives. Collectivization was heavily promoted by the Communist Party. The regime often applied various enforcement measures, such as banning workforce employment and imposing discriminatory quotas and taxes (Průcha et al., 2009, pg. 360). Farmers with more than 15 - 20 hectares (pejoratively referred to as "kulaks") were persecuted and their land was expropriated (Půlpán, 1993, pg. 240; Jech, 2008, pg. 141-146).

Act No. 69/1949 Coll. on agricultural cooperatives became the principal legal regulation for the collectivization of Czechoslovak agriculture. Section 7 par. 1 of the Act stated that every agricultural labourer was free to (voluntarily) join the cooperative (although in many cases the voluntary nature of joining the cooperative could well be doubted in reality). It is important to note that in legal terms a member of a cooperative was still the owner of the land that he or she brought to the cooperative. However, such ownership was in fact circumscribed and the owner was not allowed to take advantage of his or her property rights. Internal Communist Party documents suggest that the reason for these measures was not respect for the Constitution-granted protection of private property, but rather fears that expropriation or enforced purchase might discourage medium-sized agricultural labourers from joining cooperatives and thus make the establishment of these cooperatives more difficult (Jech, 2008, pg. 75).

The whole process of collectivization in Czechoslovakia was completed in the late 1950s. While the socialist sector's share of the farmland (consisting of agricultural cooperatives and state estates) was $46.3 \%$ in 1953, it reached $92.5 \%$ in 1960.

Collectivization in agriculture represented a serious restriction of land ownership and agricultural property rights.

Further development in the 1960s completed legislative changes in property rights, their protection and forms in Communist Czechoslovakia, which remained practically unchanged until the fall of the Communist regime in 1989. The 1982 amendment (Act No. 131/1982 Coll.) was a response to unsustainable development in the country and brought only partial changes, such as the reintroduction of a number of traditional legal institutions and adjustments to the civil law resulting from real-life needs. (Among the institutions reintroduced to the legal system were, for instance, the institute of possession, and amendments to positive prescription and user rights). At the same time, the amendment included stipulations restricting emigrants' property rights. According to $\S 453 \mathrm{a}$, should a proprietor break the law and in consequence of this unlawful action be unable to make standard use of his or her property, the state would become the owner of such property ex lege. The status quo set in the 1960s was maintained until 1989. Legislative changes in property rights within cooperatives were subject to similar development.

In summary, the Communist takeover marked fundamental changes in property rights in Czechoslovakia. The new legal regulations codified and pushed forward socialist property (state, cooperative and municipal enterprises), limited the extent of personal property, and marginalized the institution of private. 


\section{Empirical research into property rights protection}

Property rights, their importance, application and protection have been the focus ofa certain amount of previous research. However, no empirical study has (so far as we know) yet tried to provide a systematic analysis of the specifics of property rights protection in Communist regimes. For this reason, economics lacks data referring to the specific conditions in Czechoslovakia and other Communist autocracies.

The data available for Czechoslovakia during the period of Communist rule are limited to political risk indexes held by private rating agencies PRS Group (dataset ICRG) and BERI (dataset HRRP).

The data from the International Country Risk Guide (ICRG) are among the most commonly used in economic literature approximating property rights protection and the institutional environment in general (Adámek, 2014). Both indexes provide annual political risk ratings. The ICRG data are available for the period beginning 1984 for eight countries of the Eastern Bloc, while the BERI data start in 1980 and include four of the countries, including Czechoslovakia. These ratings are not based on an analysis of formal provisions, but rather reflect the real behaviour of the authorities in power (Glaeser, La Porta, Lopez-de-Silanes, \& Shleifer, 2004), i.e. de facto institutions.

Although these indexes are standardly used, they often meet with justified criticism. The data are expert ratings, and the methods used for their calculation are not publicly available, which calls their credibility into question. Furthermore, Jellema \& Roland (2011) assess the ICRG time series data as "suspiciously volatile" (e.g. see the IPI index in Figure $1^{3}$ ). This claim must be regarded as fundamental. The institutional environment is generally considered to be a very stable variable and thus the volatility of these indicators may suggest an inappropriate proxy was used for the institutional environment. On the other hand, the higher volatility in the ICRG data seems to have a significant effect on the real economy (Berggren, Bergh, \& Bjørnskov, 2012, 2015; Mikula, 2011). This, on the contrary would be proof of its credibility. The relatively volatile behaviour of the ICRG data stands in direct contrast to the very stable BERI time series (see Figure 2).

Both agencies publish a number of other partial indicators, which are used independently or as components of composite indicators. Ali et al. (2011), Knutsen (2011), and Knutsen \& Fjelde (2013) use ICRG components Investment Profile (IPI), Law and Order (LOI) and Political Risk (PRI) in their approximation of property rights. The Investment Profile Index includes ratings for contract viability (expropriation), profit repatriation, and payment delays. The Law and Order Index rates the quality of the legal system and efficiency of law enforcement in everyday life. All indicators and composite indexes used in this study use a $0-10$ scale, where higher figures represent better quality in the institutional environment.

\footnotetext{
${ }^{3}$ All figures in appendix.
} 
In addition to the Political Risk Index and its components, another composite index has been built on the ICRG data; its authors, Knack \& Keefer (1995), were among the first to use the ICRG data. Their PRP index includes the IPI and LOI again, but also takes into consideration ratings for bureaucracy and corruption. The final value is the equally weighted sum of all partial components. Their index is also used for example by Li \& Resnick (2003).

The very limited length of the time-series available does not represent a sufficient base for applying sophisticated methods of econometrics. However, it is sufficient for a basic description of states and trends of development.

All index values based on the ICRG can be seen in Figure 1. In addition to the respective values, the Figure also shows their relative level compared to advanced economies. These are represented by an average rating for the G7 countries. In case of Czechoslovakia, the Figure shows an evident slump in the IPI in the late 1980s. Time series for other indices show only slight changes, which, especially in the case of time-invariant LOI, correspond to the persistence of the status quo in the formal codification of property rights.

The Figure clearly shows that the quality of the institutional environment in Czechoslovakia lagged behind the standard in advanced economies. In fact, the Figure reveals continual divergence of indicators in the course of the entire period in focus. The only exception from this general pattern is the development of LOI. The convergence indicator for LOI suggests that this feature of the institutional environment was fully comparable to advanced economies.

The development of institutional indicators in Czechoslovakia can be compared with the situation in other countries of the Eastern Bloc. A similar trend pattern characterized by deterioration in IPI and stability in LOI can be found in the majority of the Eastern Bloc countries: Bulgaria, East Germany, Hungary and Yugoslavia. Romania recorded a slower rate of deterioration in the quality of its institutional environment and its divergence from advanced economies. This can be attributed to the fact that throughout the analyzed period (1984 - 1989), index values for Romania were very low. Among the Eastern Bloc countries, Albania, Poland and the USSR can be considered exceptions from the general deterioration and divergence pattern. Poland and Albania recorded slight improvement in the IPI and stagnation or slight deterioration in the LOI. These two countries moderately converged to the IPI of the G7 countries. The only strongly converging economy was the USSR, where Gorbaschov's reforms resulted in rapid improvement in the IPI and LOI.

The development of composite indices follows the pattern of IPI. In the case of PRP the IPI development is almost the only source of variability. However the same holds even for PRI, which also covers bureaucracy quality and corruption evaluation.

In general, Czechoslovakia followed a quite typical development pattern within the Eastern Bloc countries, characterized by divergence in IPI and composite indices and a stable level of LOI.

Despite the Eastern Bloc countries' divergence from the G7 countries, their rating did not lag behind the world average. Figure 3 shows the position of the Eastern Bloc coun- 
tries compared with the rest of the world in 1989 (the total of 126 available economies, including the Eastern Bloc). The lower rating for Yugoslavia can be considered surprising, given the relatively open state of this economy towards the West. However, most of the Eastern Bloc economies recorded average or even highly above-average figures. This can be attributed to the extremely poor institutional environment in Africa, South America, and Southeast Asia, which significantly lowered the world's average figures and thus made the position of the Eastern Bloc economies seem relatively good (see Figure 4).

For the purpose of our study we use the HRRP BERI components that are analogous to the ICRG ratings of attitude to foreign investors and profits (FIP) and enforceability of contracts (ENF). Having extended these indexes with an evaluation of bureaucratic delays, we construct the BPRP index, whose contents as well as structure is analogous to the PRP index.

The efficiency of the BERI dataset is significantly limited by the lower number of countries included. The dataset comprises 75 countries, but its figures for the 1980s include only 4 of the Eastern Bloc economies: Czechoslovakia, Hungary, Poland, and the USSR. Figure 2 shows that the BERI data are relatively stable. Unlike the ICRG, they do not take into account any changes reflecting groundbreaking reforms in the USSR, and their figures for Czechoslovakia are also, more or less, unvarying. Notable convergence is recorded in the FIP index for Hungary (whose IPI significantly diverged), as well as for Poland. In the case of Poland, the BERI data and the ICRG data show comparable trends and convergence. The convergence of Poland and Hungary might be rooted in their governments' different attitude to entrepreneurship. These countries were the only states in Eastern Bloc which allowed their citizens to run private businesses (Žídek, 2011, 2014).

Remarkable figures can be found in the ENF index for Czechoslovakia, which is the only rating in which an Eastern Bloc economy surpassed the G7 average. This, however, might raise doubts about the reliability and interpretation of the published data. Stable figures in the BERI ENF index tend to tally with the status quo in the codification and protection of property rights in Czechoslovakia.

The available data are critically insufficient to allow a thorough description or the development of a theory accounting for the property rights protection framework. There are two main reasons for this: firstly, the available data only cover a period of a few years towards the end of the Communist regimes, when the respective economies were struggling with internal disintegration, which may have affected property rights protection in a number of ways. Secondly, the nature of the available data, i.e. indexes based on expert analyses, calls their credibility and interpretation into question, as they do not offer a very high degree of interpretative certainty. This is made even more questionable due to the public unavailability of their methodology. It is probable that the ICRG and BERI data, which are primarily targeted at foreign investment risk assessment, relate more to property rights protection with regard to foreign investors' property rights, i.e. protection of precious foreign currency sources; the protection of Czechoslovak citizens' property rights may have been significantly different. 


\section{Conclusion}

Although Czechoslovak legislation took gradual steps during the Communist period towards diminishing the status of private property, no laws were passed that officially or entirely terminated its existence. The legislation of the 1960 s set a status quo which codified property rights until the fall of the Communist regime in 1989.

An analysis of the formal codification of property rights in the Civil Law is the cornerstone of any research into the institutional environment of a Communist economy. However, it cannot tell us what it was really like, or howthe regime actually protected its citizens' property rights. Did the regime show respect for its own laws, or did it play by different, uncodified rules? From the point of view of economic analysis, this difference is of fundamental value. As stated above, the economic literature clearly differentiates between property rights de facto and de iure (see Williamson (1996)). Unless economic agents act in a totally irrational way, they must distinguish differences (if such exist) between the authorities' officially declared behaviour and their real behaviour. The most logical conclusion is that these agents will adapt their behaviour to match the real (de facto) conditions and institutions.

An analysis of empirical research into the real functioning of the property rights environment could offer a more thorough insight. Unfortunately, due to ambiguous interpretations and limited time series datasets for Communist autocracies, such ratings must be regarded rather as supplementary criteria. ICRG indicators used in this analysis show that in the course of the 1980s, property rights protection in Czechoslovakia did not record any dramatic changes, although during this period the country gradually diverged from the standard of property rights protection in developed economies. In this respect, the ICRG data are not in accord with the BERI data, which show a steady degree of property rights protection and their constant relation to advanced economies. The absence of dramatic changes in the indices evaluated is generally in accordance with the observed maintenance of the status quo in legislation.

Accounting for the real functioning of the institutional environment is essential for a true insight into the functioning of the Communist economy in Czechoslovakia, as well as it is necessary for thorough comprehension of the consequent economic transformation that was conditioned by the institutional environment set by the Communist regime. However, the degree of insight into the real functioning of property rights protection and its enforcement that is currently available to us does not provide a sufficient and reliable interpretation.

\section{Acknowledgement}

Publication of this paper was supported by specific research project MUNI/A/0844/2013 and Czech Science Foundation grant No. GA15-09404S. 


\section{References}

ADÁMEK, J. (2014) Indicators of Institutional Quality. In Conference proceedings 12th International Scientific Conference "Economic Policy in the European Union Member Countries”. Opava: Slezská univerzita v Opavě.

ALI, F., FIESS, N., \& MacDONALD, R. (2011). Climbing to the top? Foreign direct investment and property rights. Economic Inquiry, 49(1), 289-302.

BARZEL, Y. (1997) Economic analysis of property rights. Cambridge: Cambridge University Press.

BERGGREN, N., BERGH, A. \& BJØRNSKOV, C. (2012) The growth effects of institutional instability, Journal of institutional economics, 8(2), 187-224. DOI: $10.1017 / \mathrm{S} 1744137411000488$

BERGGREN, N., BERGH, A. \& BJØRNSKOV, C. (2015). What matters for growth in Europe? Institutions versus policies, quality versus instability. Journal of Economic Policy Reform, 18(1), 69-88. DOI: 10.1080/17487870.2014.953159

BĚLOVSKÝ, P. (2009) Občanské právo. In BOBEK M., MOLEK, P. \& ŠIMÍČEK, V. (eds.). Komunistické právo v Československu: kapitoly z dějin bezpráví. Brno: Masarykova univerzita, Mezinárodní politologický ústav.

DE ALESSI, L. (1983) Property Rights, Transaction Costs, and X-Efficiency: An Essay in Economic Theory, The American Economic Review, 73(11), 64-81.

DEMSETZ, H. \& ALCHIAN, A. (1973) The property right paradigm, The Journal of Economic History, 33(1), 16-27. DOI: 10.1017/S0022050700076403

DEMSETZ, H. (1966) Some Aspects of Property Rights, Journal of Law and Economics, 9(1), 61-70. DOI: 10.1086/466619

GLAESER, E. L., LA PORTA, R., LOPEZ-DE-SILANES, F. \& SHLEIFER, A. (2004) Do Institutions Cause Growth? Journal of Economic Growth, 9(3), 271-303. DOI: 10.1023/B:JOEG.0000038933.16398.ed

JÁNOŠÍKOVÁ, P., V. KNOLL, \& A. RUNDOVÁ (2010) Mezníky českých právních dějin. Plzeň: Aleš Čeněk.

JECH, K. (2008) Kolektivizace a vyhánění sedláki̊ z půdy. Praha: Vyšehrad.

JELLEMA, J. \& ROLAND, G. (2011) Institutional clusters and economic performance, Journal of Economic Behavior \& Organization, 79,(1) 108-132. DOI: 10.1016/j.jebo.2011.04.003

KINCL, J., V. URFUS, \& SKŘEJPEK, M. (1995) Řimské právo, Praha: C.H. Beck.

KNACK, S. \& KEEFER, P. (1995) Institutions and Economic Performance: CrossCountry Tests Using Alternative Instituitonal Measures, Economics and Politics, 7(3), 207-227. DOI: 10.1111/j.1468-0343.1995.tb00111.x

KNUTSEN, C. H. (2011) Democracy, Dictatorship and Protection of Property Rights. Journal of Development Studies, 47(1), 164-182. DOI: 10.1080/00220388.2010.506919 
KNUTSEN, C. H. \& FJELDE, H. (2013) Property rights in dictatorships: kings protect property better than generals or party bosses. Contemporary Politics, 19(1), 94-114. DOI: $10.1080 / 13569775.2013 .773205$

KUKLÍK, J. (2010) Znárodněné Československo : od znárodněni k privatizaci - státní zásahy do vlastnických a dalších majetkových práv v Československu a jinde v Evropè. Praha: Auditorium.

LEBLANG, D. (1996) Property Rights, Democracy and Economic Growth, Political Research Quarterly, 49(1), 5-26. DOI: 10.1177/106591299604900102

LI, Q., \& RESNICK, A. (2003). Reversal of fortunes: Democratic institutions and foreign direct investment inflows to developing countries. International organization, 57(01), 175-211.

MIKULA, Š. (2011) On the Predictability of Institutional Environment. In DLOUHÝ, M. \& SKOČDOPOLOVÁ, V. (eds.). Mathematical Methods in Economics 2011, Praha: University of Economics, Prague, Faculty of Informatics and Statistics, Prague.

MIKULA, Š. (2012). Autokracie a ochrana vlastnických práv. Ekonomický časopis, (05), 528-543.

MLČOCH, L. (1990) Chováni československé podnikové sféry. Praha: Ekonomický ústav ČSAV.

MLČOCH, L. (2000) Restrukturalizace vlastnických vztahů: institucionální pohled. In MLČOCH, L., MACHONIN, P. \& SOJKA, M. (eds.). Ekonomické a společenské změny $\checkmark$ české společnosti po roce 1989 : alternativni pohled. Praha: Karolinum.

NORTH, D. (1990) Institutions, institutional change, and economic performance. Cambridge: Cambridge University Press.

PRŮCHA, V. ET AL. (2009) Hospodářské a sociálni dějiny Československa 19181992. Brno: Doplněk.

PŮLPÁN, K. (1993) Nástin českých a československých hospodárských dějin do roku 1990, Praha: Karolinum.

WILLIAMSON, O. E. (1996) The mechanisms of governance. New York: Oxford University Press.

ŽÍDEK, L. (2011). Transformation in Poland. Review of Economic Perspectives, 11(4), 237-270. DOI: 10.2478/v10135-011-0015-x

ŽÍDEK, L. (2014). Evaluation of Economic Transformation in Hungary. Review of Economic Perspectives, 14(1), 55-88. DOI: 10.2478/revecp-2014-0004 


\section{Appendix}

Figure 1 (p. 342) ICRG data-based indices in Eastern Bloc countries, Note: Linear trends are in red.

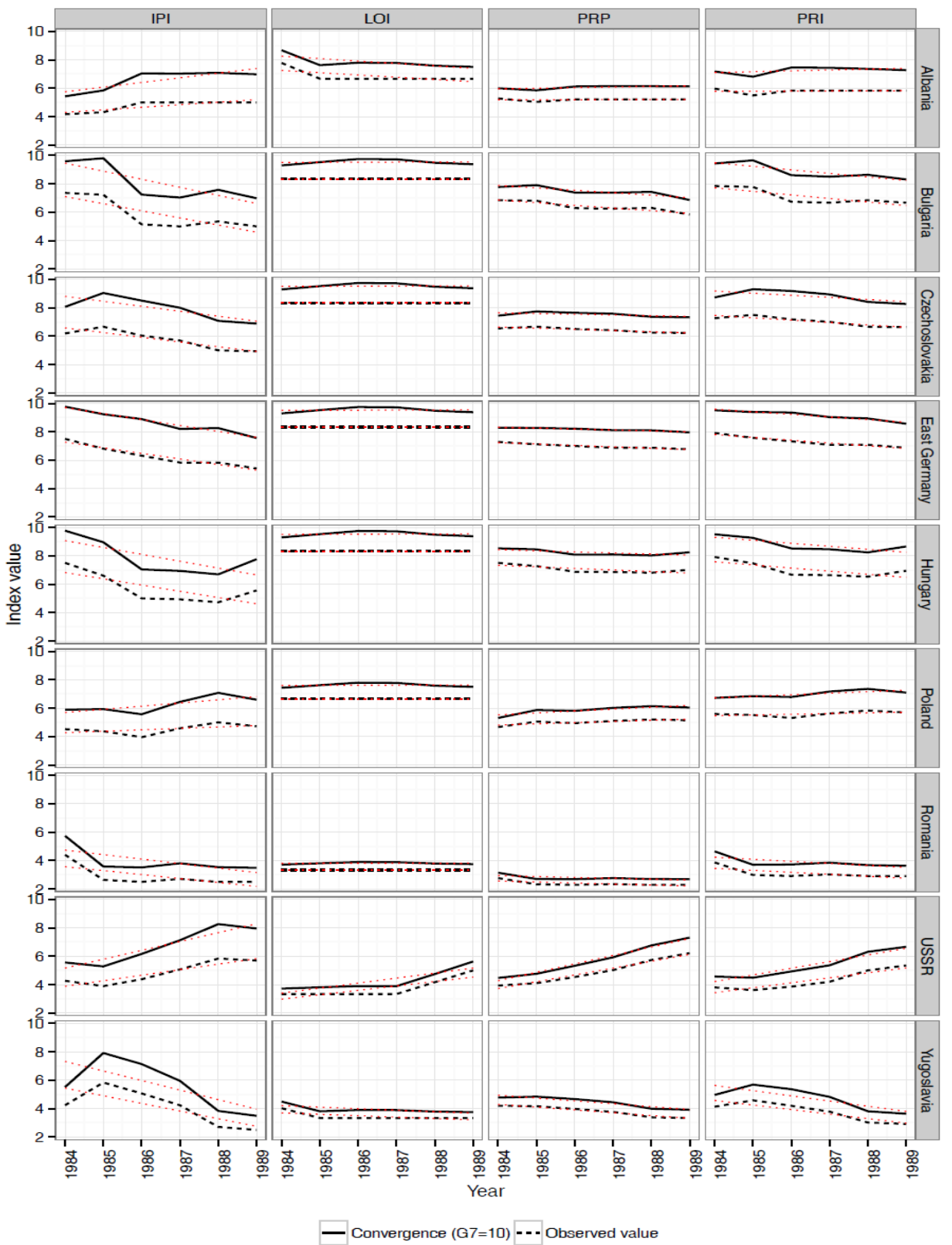


Figure 2 (p. 343) BERI data-based indices in Eastern Bloc countries, Note: Linear trends are in red.

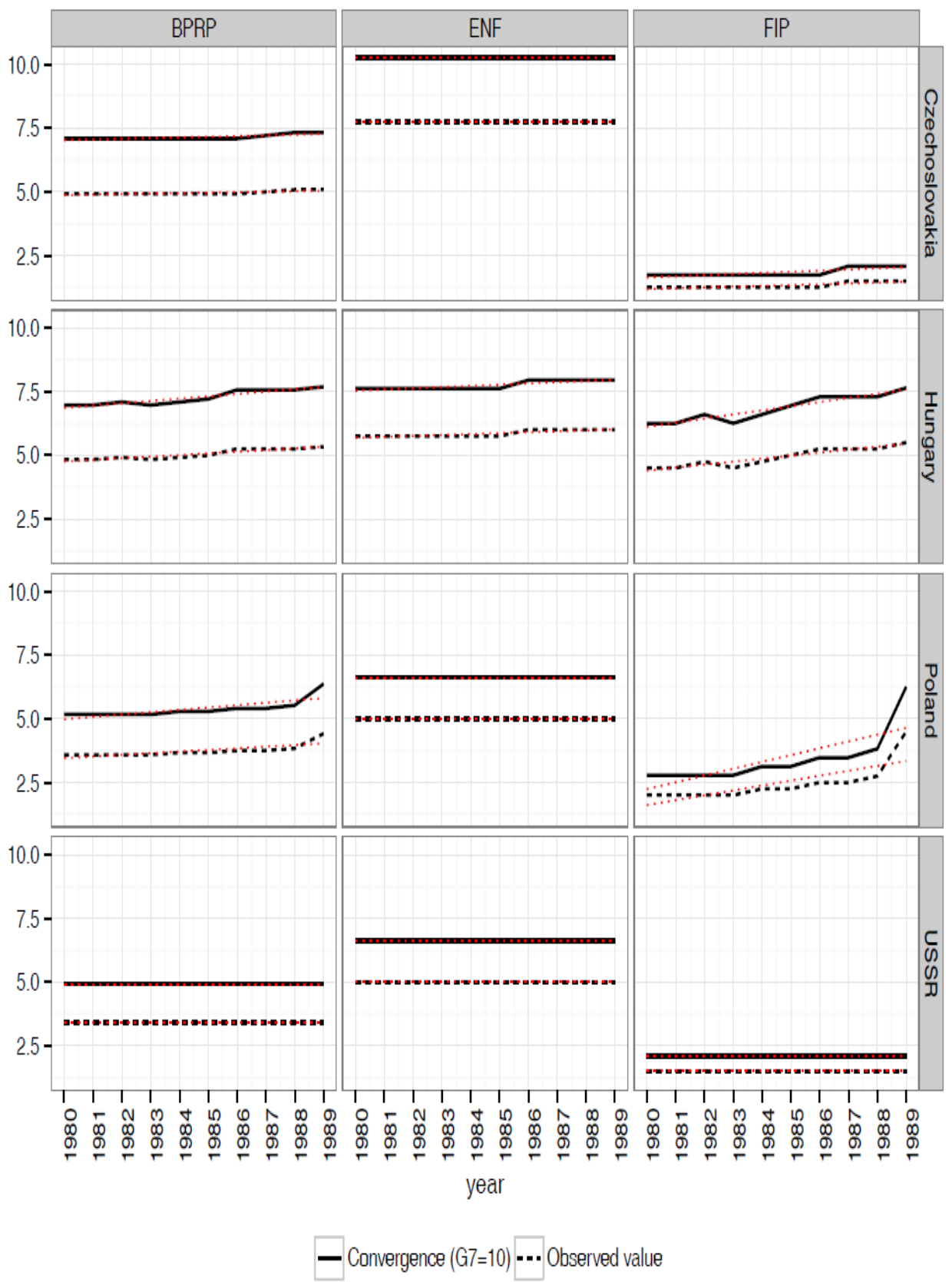


Figure 3 (p. 344) ICRG data-based indices: World population (126 countries) and the Eastern Bloc states in 1989.

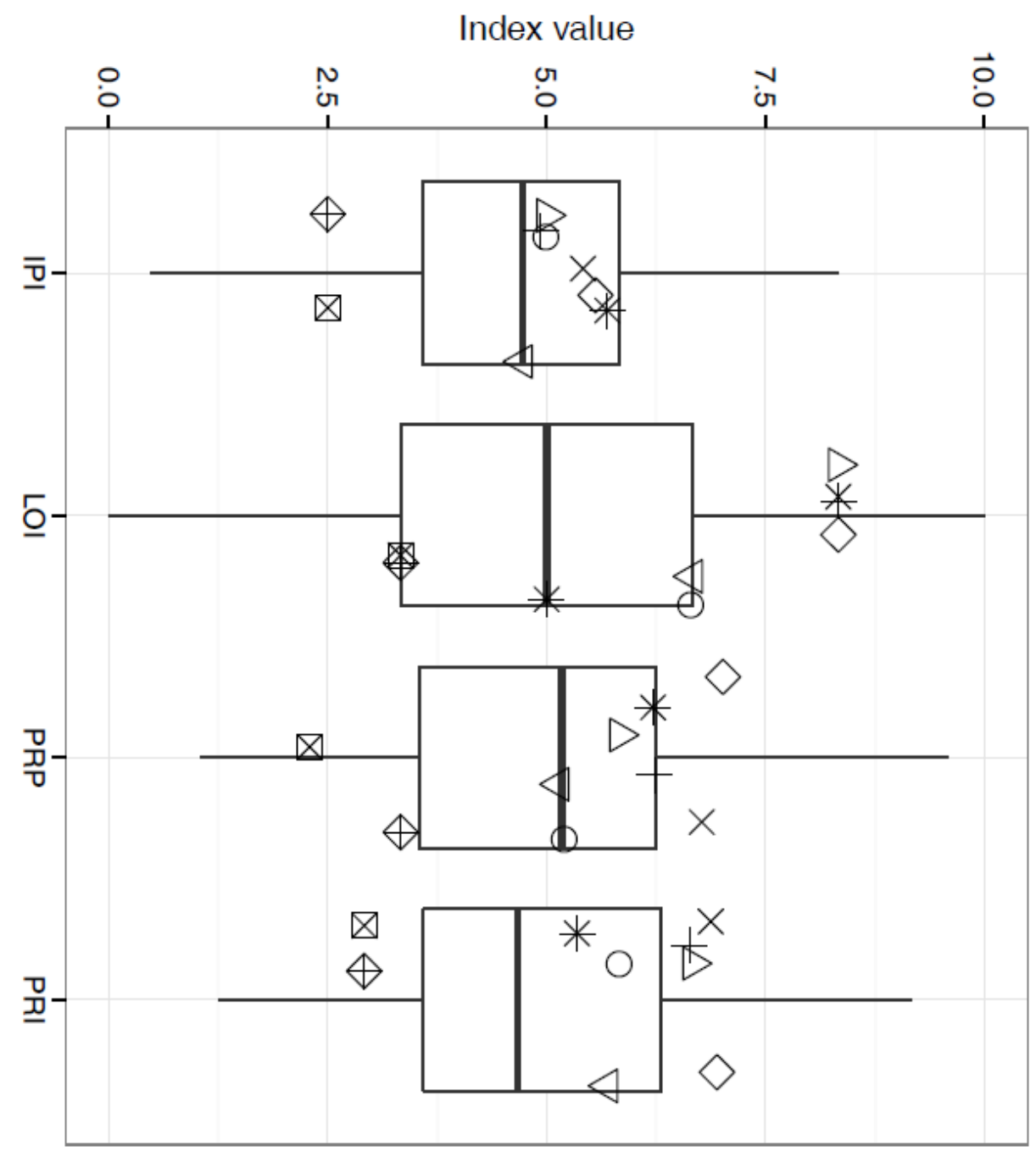

$$
\begin{aligned}
& \mapsto * \Delta\langle\diamond \times+D O
\end{aligned}
$$

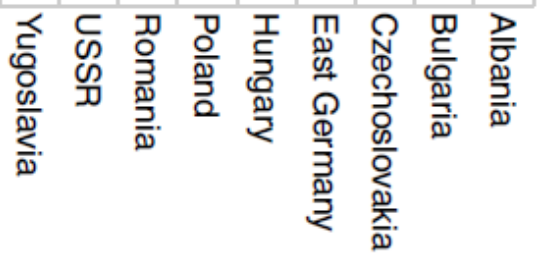


Figure 4 (p. 345) Distribution of ICRG-based indices around the world in 1989
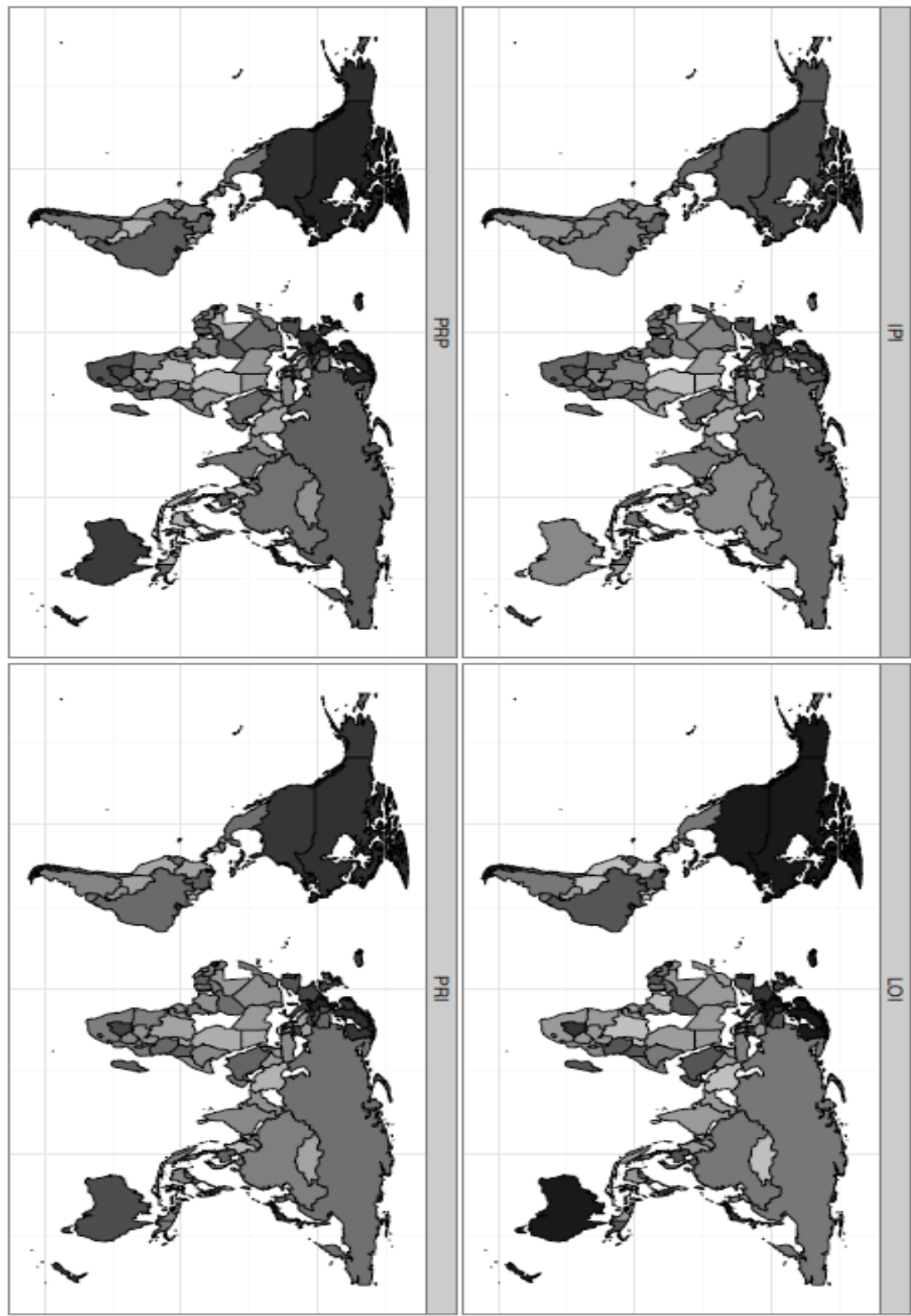

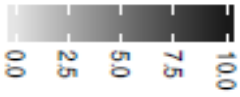

